\title{
BIAYA OPERASIONAL PENGARUHNYA KEPADA LABA USAHA PADA PT. PRIMA TRANSPORTASI
}

\author{
Hasni \\ Program Studi Manajemen, Fakultas Ekonomi \\ Universitas Muhammadiyah Buton, Baubau, Indonesia \\ e-mail: hasni76hasni@gmail.com
}

\begin{abstract}
ABSTRAK
Tujuan penelitian ini adalah untuk mengetahui pengaruh biaya operasional terhadap laba usaha pada PT. Prima Transportasi. Metode pengumpulan data yang digunakan dalam penelitian ini adalah studi kepustakaan, wawancara dan observasi. Sedangkan metode analisis data yang digunakan untuk menganalisis pengaruh biaya operasional terhadap laba usaha pada PT. Prima Transportasi digunakan metode regresi linear sederhana, analisis koefisien korelasi, analisis koefisien determinasi, dan pengujian hipotesis yakni dengan membandingkan nilai $t_{\text {hitung }}$ dengan nilai $t$ pada distribusi $t$ tabel $\left(\mathrm{t}_{\text {tabel }}\right)$, dimana analisis data dalam penelitian ini dilakukan dengan bantuan aplikasi SPSS versi 22.

Berdasarkan hasil pengujian hipotesis, diperoleh nilai $t_{\text {hitung }}$ sebesar 14,874 dimana masih lebih besar daripada nilai $\mathrm{t}$ pada distribusi $\mathrm{t}$ tabel $\left(\mathrm{t}_{\text {tabel }}\right)$ yakni berkisar pada angka 1,687 sehingga dapat diketahui bahwa adanya pengaruh negatif signifikan biaya operasional terhadap laba usaha pada PT. Prima Transportasi. Sesuai hasil analisis regresi linear sederhana ditemukan persamaan $\mathrm{Y}=383,670+$ 0,134X, dimana diketahui nilai konstanta yaitu sebesar Rp. 383,670 dan bilamana dalam sebulan terjadi pengeluaran biaya operasional sebesar Rp. $1(\mathrm{X}=1)$ maka diperkirakan hanya akan memberikan laba usaha sebesar Rp. 0,134. Berdasarkan hasil analisis koefisien korelasi diperoleh nilai korelasi berangka 0,93 dimana berada pada kisaran nilai pengaruh 0,90-1,00 sehingga diketahui bahwa biaya operasional dan laba usaha pada PT. Prima Transportasi memiliki hubungan yang sangat kuat, kemudian sesuai hasil analisis koefisien determinasi ditemukan nilai koefisien determinasi yaitu sebesar $86,7 \%$ yang menyatakan bahwa tingkat pengaruh biaya operasional terhadap laba usaha pada PT. Prima Transportasi yaitu sebesar $86,7 \%$ dan $13,3 \%$ lainnya dipengaruhi oleh faktor lain yang tidak diteliti dalam penelitian ini.
\end{abstract}

\section{Kata Kunci: Biaya, Biaya Operasional, Laba Usaha}

\section{ABSTRACT}

The purpose of this study is to determine the effect of operating costs on operating income at PT. Prima Transportation. Data collection methods used in this study are library studies, interviews and observations. While the data analysis method used to analyze the influence of operating costs on operating income at PT. Prima Transportation uses simple linear regression method, correlation coefficient analysis, coefficient of determination analysis, and hypothesis testing that is by comparing the tcount value with $t$ value on $t$ table distribution ( $t$ table), where data analysis in this study was carried out with the help of SPSS version 22 application.

The results of hypothesis testing, obtained a value of tcount of 14.874 where it is still greater than the value of $t$ in the distribution of $t$ table ( $t$ table) which is around the number 1.687 so that it can be seen that there is a significant negative effect of operating costs on operating income at PT. Prima Transportation. According to the results of a simple linear regression analysis, the equation $Y$ $=383,670+0,134 X$, where the constant value is Rp. 383,670 and if in a month there is an operational cost of Rp. $l(X=1)$ it is estimated that it will only give an operating profit of Rp. 0.134. Based on the results of the correlation coefficient analysis, the value of the correlation is 0.93 which is in the range of the influence value of 0.90-1.00 so that it is known that operating costs and operating profit at PT. Prima Transportation has a very strong relationship, then according to the 
results of the coefficient of determination analysis found the coefficient of determination is equal to $86.7 \%$ which states that the level of influence of operating costs on operating income at PT. Prima Transportasi is $86.7 \%$ and the other $13.3 \%$ is influenced by other factors not examined in this study.

Keywords: Cost, Operating Costs, Operating Profit

\section{PENDAHULUAN}

PT. Prima Transportasi merupakan salah satu perusahaan yang bergerak dalam bidang pelayanan jasa transportasi (taksi). Sebagai perusahaan yang berorientasi profit dimana senantiasa dinilai kinerjanya oleh pihak manajemen perusahaan, agar selain memberikan kepuasan pelayanan kepada masyarakat pengguna jasa transportasi, PT. Prima Transportasi juga harus meningkatkan kemampuan untuk merealisasikan tujuantujuannya yang termasuk didalamnya adalah meningkatkan perolehan laba usaha perusahaan. Perolehan laba usaha dapat diketahui dengan adanya laporan laba-rugi. Laporan laba-rugi merupakan laporan mengenai pendapatan, biaya-biaya dan laba perusahaan selama periode tertentu [1]. Laporan laba-rugi adalah laporan yang menunjukkan hasil kegiatan perusahaan dalam jangka waktu tertentu, yang bisa digunakan sebagai indikator keberhasilan perusahaan dalam menjalankan usahanya selama satu periode tertentu [2].

Secara umum, perolehan laba usaha sangat ditentukan oleh besar kecilnya biaya

yang digunakan oleh perusahaan dalam menjalankan kegiatannya. Laba adalah perbedaaan positif sebagai hasil penjualan produk-produk dan jasa-jasa dengan harga lebih tinggi dari pada biaya untuk menghasilkan barang tersebut [3]. Selanjutnya laba (income) ialah pengembalian (return) yang melebihi investasi [4].

Perhitungan laba rugi, biaya yang dapat mengurangi laba perusahaan atau menambah rugi perusahaan ialah besarnya biaya operasional [5].Biaya operasional adalah biaya-biaya yang berkaitan dengan kegiatan-kegiatan administratif dan penjualan dari suatu perusahaan [6]. Biaya operasional adalah biaya usaha pokok perusahaan selain harga pokok penjualan [7]. Biaya usaha terdiri dari biaya penjualan, biaya administrasi dan umum. Biaya operasional adalah harga pokok penjualan ditambah biaya administrasi dan umum serta biaya penjualan [8].Dalam perhitungan laba rugi, besarnya biaya operasional akan mengurangi laba atau menambah rugi perusahaan, sehingga salah satu cara yang dapat ditempuh untuk memperoleh laba usaha yang lebih optimal adalah dengan benar-benar mengestimasi pengendalian atas pengeluaran biaya operasional [9]. 
Apabila pengeluaran biaya operasional dapat dikendalikan secara efektif, maka akan sangat berpengaruh terhadap peningkatan laba usaha perusahaan, sebaliknya jika biaya operasional tidak dapat dikendalikan secara efektif maka akan terjadi pemborosan.

Berdasarkan uraian latar belakang diatas, sehingga penulis tertarik untuk melakukan penelitian pada PT. Prima Transportasi dan penelitian ini akan dituangkan lebih lanjut dengan judul "Pengaruh Biaya Operasional Terhadap Laba Usaha Pada PT. Prima Transportasi”.

\section{METODE PENELITIAN}

Penelitian ini akan dilaksanakan pada PT. Prima Transportasi yang beralamat di Jalan Bonecom, Kelurahan Katobengke, Kota Baubau dengan menggunakan laporan rugi laba PT. Prima Transportasi sebagai populasi dengn penarikan sampel biaya operasional dan laba usaha pada laporan laba rugi PT. Prima Transportasi periode Juli-Desember 2015, Januari-Desember 2016 serta Januari-Desember 2017. Penelitian ini menggunakan data kualitatif dan kuantitatif. Data kualitatif yaitu data yang didasarkan pada keadaan perusahaan yang akan dijadikan objek penelitianyang dianalisa dengan menguraikan fakta-fakta. Data ini berupa gambaran umum dan struktur organisasi PT. Prima Transportasi serta teori-teori yang mendasari penelitian ini sementara data kuantitatif yaitu data yang menjelaskan pengaruh, dalam hal ini adalah biaya operasional terhadap laba usaha. Data ini meliputi jumlah biaya operasional dan laba usaha dalam rupiah yang dinyatakan dengan angka-angka berdasarkan hasil perhitungan dari analisis dengan menggunakan rumus statistika.

Teknik pengumpulan data yang digunakan ialah studi kepustakaan yaitu data ini dilakukan dengan menelaah berbagai dokumen-dokumen perusahaan serta tulisan-tulisan ilmiah yang berkaitan erat dengan masalah yang diteliti dimana data diperoleh secara tidak langsung dan penelitian lapangan yaitu melakukan observasi dan wawancara secara langsung dengan pihak perusahaan dengan sumber data primer dan sekunder. Data yang dikumpulkan oleh peneliti dianalisa menggunakan metode regresi linear sederhanadimana metode ini digunakan untuk menganalisis pengaruh biaya operasional terhadap laba usaha pada PT. Prima Transportasi melalui uji normalitas data, koefisien korelasi, pengujian hipotesis dan koefisien korelasi. Berikut merupakan operasionalisasi variabel dalam peneltian ini. 


\section{Tabel 1. Operasionalisasi Variabel}

\begin{tabular}{|c|c|}
\hline Variabel & Konsep Variabel \\
\hline Biaya Operasional(X) & "Biaya yang berkaitan dengan aktivitas operasional \\
perusahaan selain biaya produksi”. \\
(Jopie Jusuf, 2008:33)
\end{tabular}

\section{HASIL DAN PEMBAHASAN}

\section{a. Hasil Penelitian}

\section{1) Laporan Laba Rugi PT. Prima Transportasi}

Laporan laba rugi merupakan laporan mengenai pendapatan, beban dan laba atau rugi perusahaan dalam suatu periode tertentu. Setiap perusahaan yang berorientasi profit tentunya akan memerlukan laporan laba rugi. Begitu pula pada PT. Prima Transportasi dimana komponen-komponen laba rugi perusahaan selalu dicatat dan dilaporkan pada setiap akhir bulan. Dalam laporan laba rugi PT. Prima Transportasi, ada tiga komponen utama laba rugi yang selalu dilaporkan pada akhir periode pelaporan. Adapun komponen-komponen laba rugi yang dimaksud adalah:

1. Pendapatan usaha, yakni merupakan pendapatan utama dari tujuan didirikannya perusahaan tersebut.

2. Beban usaha, dimana dalam menjalankan kegiatan usahanya PT. PrimaTransportasi selalu dihadapkan dengan berbagai beban sebagai biaya operasional perusahaan antara beban gaji dan bonus, beban telepon, beban listrik dan air, beban perlengkapan kantor, beban penyusutan peralatan kantor, beban pemeliharaan (taksi), dan beban bahan bakar.

3. Laba usaha, dimana merupakan selisih lebih dari pendapatan usaha perusahaan setelah dikurangi biaya operasional perusahaan.

\section{2) Pengeluaran Biaya Operasional Pada PT. Prima Transportasi}

Perusahaan pada umumnya berusaha untuk terus meningkatkan kualitas produknya. Hal ini dilakukan sebagai salah satu usaha dalam mencapai tujuan peruasahaan pada umumnya yaitu untuk mencapai laba yang sebesar-besarnya. Berkembangnya teknologi dan berbagai bidang lainnya dalam kehidupan memberi dampak yang 
cukup signifikan terhadap perkembangan kebutuhan, keinginan dan selera konsumen akan suatu produk barang atau jasa yang akan dipakai. Perkembanganperkembangan dalam dunia bisnis secara keseluruhan memberi perubahan orientasi bisnis perusahaan pada umumnya.

Setiap perusahaan pada umumnya dalam melaksanakan kegiatan usahanya akan dihadapkan dengan pengeluaran biaya operasional. Biaya operasional adalah biaya-biaya yang tidak berhubungan langsung dengan produk perusahaan tetapi berkaitan dengan aktivitas operasinal perusahaan sehari-hari [10]. Biaya operasional (biaya usaha) sering disebut juga dengan istilah SGA (Selling, General dan Administrative Expenses).

Berdasarkan uraian sebelumnya telah dijelaskan mengenai komponenkomponen utama laba rugi pada PT. Prima Transportasi diantara beban usaha pada PT. Prima Transportasi, dimana dalam menjalankan kegiatan usahanya dihadapkan dengan beban usaha sebagai biaya operasional perusahaan. Berikut adalah data atas pengeluaran biaya operasional PT. Prima Transportasi selama tiga tahun dimana dapat dilihat pada tabel 2 berikut:

Tabel 2. Data Pengeluaran Biaya Operasional PT. Prima Transportasi (Terhitung Tiap periode Akuntansi)

\begin{tabular}{|c|c|c|}
\hline No. & Bulan/Tahun & Biaya Operasional \\
\hline 1. & Januari 2015 & Rp. $\quad 27,000,000$ \\
\hline 2. & Februari 2015 & Rp. $\quad 27,500,000$ \\
\hline 3. & Maret 2015 & $\begin{array}{ll}\text { Rp. } & 27,400,000\end{array}$ \\
\hline 4. & April 2015 & Rp. $\quad 27,600,000$ \\
\hline 5. & Mei 2015 & $\begin{array}{ll}\text { Rp. } & 27,500,000\end{array}$ \\
\hline 6. & Juni 2015 & Rp. $\quad 27,600,000$ \\
\hline 7. & Juli 2015 & Rp. $\quad 27,500,000$ \\
\hline 8. & Agustus 2015 & $\begin{array}{ll}\text { Rp. } & 28,000,000\end{array}$ \\
\hline 9. & September 2015 & Rp. $\quad 27,500,000$ \\
\hline 10. & Oktober 2015 & $28,500,000$ \\
\hline 11. & November 2015 & $28,500,000$ \\
\hline 12. & Desember 2015 & Rp. $\quad 29,000,000$ \\
\hline 13. & Januari 2016 & Rp. $\quad 28,510,000$ \\
\hline 14. & Februari 2016 & $\begin{array}{ll}\text { Rp. } & 29,510,000\end{array}$ \\
\hline 15. & Maret 2016 & Rp. $\quad 29,010,000$ \\
\hline 16. & April 2016 & Rp. $\quad 29,510,000$ \\
\hline 17. & Mei 2016 & $29,510,000$ \\
\hline
\end{tabular}




\begin{tabular}{|c|c|c|}
\hline 18. & Juni 2016 & Rp. $29,010,000$ \\
\hline 19. & Juli 2016 & Rp. $29,010,000$ \\
\hline 20. & Agustus 2016 & Rp. $29,510,000$ \\
\hline 21. & September 2016 & Rp. $30,010,000$ \\
\hline 22. & Oktober 2016 & Rp. $30,010,000$ \\
\hline 23. & November 2016 & Rp. $30,510,000$ \\
\hline 24. & Desember 2016 & Rp. $30,010,000$ \\
\hline 25. & Januari 2017 & Rp. $30,520,000$ \\
\hline 26. & Februari 2017 & Rp. $30,520,000$ \\
\hline 27. & Maret 2017 & Rp. $30,820,000$ \\
\hline 28. & April 2017 & Rp. $30,820,000$ \\
\hline 29. & Mei 2017 & Rp. $30,720,000$ \\
\hline 30. & Juni 2017 & Rp. $30,920,000$ \\
\hline 31. & Juli 2017 & Rp. $31,020,000$ \\
\hline 32. & Agustus 2017 & Rp. $30,020,000$ \\
\hline 33. & September 2017 & Rp. $30,520,000$ \\
\hline 34. & Oktober 2017 & Rp. $31,520,000$ \\
\hline 35. & November 2017 & $31,520,000$ \\
\hline 36. & Desember 2017 & \\
\hline
\end{tabular}

Sumber: Laporan Laba Rugi PT. Prima Transportasi 2015-2017

\section{3) Perolehan Laba Usaha Pada PT. Prima Transportasi}

Secara umum, laba usaha senantiasa dijadikan sebagai ukuran atas kesuksesan operasi perusahaan. Meningkat atau menurunnya perolehan laba usaha akan menentukan strategi yang akan datang, dimana perusahaan akan mempunyai ukuranukuran tersendiri atas toleransi meningkat atau menurunnya perolehan laba usaha tersebut. Laba usaha adalah selisih lebih antara pendapatan yang telah direalisasi dengan biaya yang terjadi untuk mendapatkan pendapatan tersebut [11].

\section{b. Pembahasan}

\section{1) Pengaruh Biaya Operasional Terhadap Laba Usaha Pada PT. Prima} Transportasi

Sesuai dengan tujuan penelitian ini yaitu untuk mengetahui pengaruh biaya operasional terhadap laba usaha pada PT. Prima Transportasi, maka data-data mengenai jumlah biaya operasional dan laba usaha yang diperoleh akan diolah ke dalam rancangan analisis yaitu uji regresi linear sederhana, analisis koefisien korelasi, analisis koefisien determinasi dan uji hipotesis. Dalam perhitungan laba rugi besarnya biaya operasional akan menambah rugi perusahaan [12]. 


\section{a) Hasil Regresi Liniear Berganda}

Adapun hasil analisis data mengenai pengaruh biaya operasional terhadap laba usaha pada PT. Prima Transportasi dapat dilihat dari hasil Uji Regresi Linear Sederhana. Analisis regresi linear sederhana dalam penelitian ini untuk meramalkan bagaimana besar laba usaha apabila biaya operasional diketahui, yang dimana dinyatakan dengan rumus:

$$
\mathbf{Y}=\mathbf{a}+\mathbf{b X}
$$

Adapun untuk mengetahui nilai konstanta (a) dan koefisien biaya operasional (b), maka dengan bantuan program aplikasi SPSS versi 22 diperoleh nilai-nilai untuk regresi linear sederhana yang seperti pada tabel 3 sebegai berikut:

\section{Tabel 3. Hasil Uji Regresi Linear Sederhana}

\section{Coefficients $^{\mathrm{a}}$}

\begin{tabular}{|l|r|r|r|r|r|}
\hline \multirow{2}{*}{ Model } & \multicolumn{4}{|c|}{ Unstandardized Coefficients } & \multicolumn{2}{|c|}{$\begin{array}{c}\text { Standardized } \\
\text { Coefficients }\end{array}$} & & \\
\cline { 2 - 4 } & \multicolumn{1}{|c|}{$\mathrm{B}$} & Std. Error & \multicolumn{1}{c|}{ Beta } & \multicolumn{1}{c|}{$\mathrm{t}$} & Sig. \\
\hline $\begin{array}{l}\text { (Constant) } \\
\text { Biaya } \\
\text { Operasional }\end{array}$ & 383.670 & 26.485 & & 14.486 & .000 \\
& .134 & .009 & .931 & 14.874 & .000 \\
\hline
\end{tabular}

a. Dependent Variable: Laba Usaha

Sumber: Data Olahan SPSS versi 22

Berdasarkan tabel 3 di atas terlihat jelas bahwa nilai konstanta (a) adalah sebesar 383,670 dan koefisien biaya operasional (b) adalah sebesar 0,134. Berdasarkan hasil analisis tersebut di atas, maka dapat disusun dengan persamaan regresi linear sederhana sebagai berikut:

$$
Y==383,670+0,134 X
$$

Persamaan tersebut di atas menjelaskan bahwa pada saat pengeluaran biaya operasional dalam satu periode akuntansi adalah sama dengan konstan, maka diasumsikan perolehan laba usaha pada PT. Prima Transportasi yaitu sebesar Rp. 383,670 dan jika dalam satu periode akuntansi besarnya biaya operasional yang dikeluarkan oleh PT. Prima Transportasi adalah sebesar Rp. $1(X=1)$ maka diperkirakan hanya akan menghasilkan laba usaha sebesar Rp. 0,134. Atau dengan kata lain, jika dalam sebulan diketahui pengeluaran biaya operasional adalah konstan $(\mathrm{X}=0$ ), diasumsikan laba usaha adalah sebesar Rp. 383,670. Dan jika dalam sebulan terjadi pengeluaran biaya operasional sebesar Rp. $1.000 .000(X=1.000 .000)$ maka 
diperkirakan hanya akan menghasilkan laba usaha sebesar Rp. $134.000(0,134$ x Rp. 1.000.000).

\section{b) Analisis Koefisien Korelasi}

Analisis koefisien korelasi digunakan untuk mengetahui bagaimana hubungan biaya operasional terhadap laba usaha yang dimana dapat diketahui melalui arah nilai korelasi berkisar rentan 0 sampai 1 atau -1. Dengan bantuan komputer program SPSS versi 22 maka diperoleh hasil analisis koefisien korelasi yang ditunjukan seperti tabel 4 sebagai berikut:

\section{Tabel 4. Hasil Analisis Koefisien Korelasi}

\begin{tabular}{|l|c|r|r|r|}
\hline Model & \multicolumn{1}{|c|}{ R } & R Square & Adjusted R Square & Std. Error of the Estimate \\
\hline 1 & $.931^{\mathrm{a}}$ & .867 & .863 & 7.217 \\
\hline
\end{tabular}

a. Predictors: (Constant), Biaya Operasional

Sumber: Data Olahan SPSS versi 22

Berdasarkan tabel 4 di atas, dapat dilihat bahwa nilai koefisien korelasi adalah sebesar 0,931 (0,93) dimana berada di antara nilai pengaruh 0,90-1,00 yang menyatakan bahwa pengaruh korelasi antara biaya operasional terhadap laba usaha pada PT. Prima Transportasi memiliki pengaruh yang sangat kuat.

\section{c) Analisis Koefisien Determinasi}

Analisis koefisien determinasi digunakan untuk mengetahui seberapa besar pengaruh yang diberikan biaya operasional terhadap laba usaha pada PT. Prima Transportasi. Pada tabel 4 sebelumnya, dapat dilihat bahwa $R$ Square adalah sebesar 0,867. Jadi, untuk mengetahui seberapa besar persentase variabel laba usaha pada PT. Prima Transportasi dipengaruhi oleh biaya operasioal yaitu dapat dicari dengan persamaan:

$$
\begin{aligned}
\mathrm{KD} & =(\mathrm{R})^{2} \times 100 \% \\
& =0,867 \times 100 \% \\
& =86,7 \%
\end{aligned}
$$

Berdasarkan perhitungan di atas, maka dapat disimpulkan bahwa besarnya pengaruh biaya operasional terhadap laba usaha pada PT. Prima Transportasi adalah sebesar $86,7 \%$ dan $13,3 \%$ lainnya dipengaruhi oleh faktor lain yang tidak diteliti dalam penelitian ini. 


\section{d) Pengujian Hipotesis}

Berdasarkan perumusan hipotesis dalam penelitian ini yaitu "Diduga adanya pengaruh negatif signifikan biaya operasional terhadap laba usaha pada PT. Prima Transportasi”, maka untuk mengukur tingkat signifikasi, hal pertama yang perlu diketahui adalah nilai $\mathrm{t}\left(\mathrm{t}_{\text {tabel }}\right)$ pada tabel distribusi $\mathrm{t}$ yang dimana dapat dicari dengan persamaan:

$$
\begin{aligned}
\mathrm{t}_{\text {tabel }} & =\alpha(\mathrm{n}-2) \\
& =0,05(36-2) \\
& =0,05(34) \\
& =1,687
\end{aligned}
$$

Hasil perhitungan di atas ditemukan nilai t pada distribusi ttabel yaitu sebesar 1,687 dan pada tabel 3 terlihat jelas bahwa nilai $t_{\text {hitung }}$ adalah sebesar 14,874. Sesuai dengan rancangan pengujian hipotesis, maka dari hasil perhitungant ${ }_{\text {hitung }}$ dan melihat nilai $t_{\text {tabel, }}$ maka akan ditarik kesimpulan:

1. Jika $t_{\text {hitung }}<\mathrm{t}_{\text {tabel }}$, maka hipotesis ditolak.

2. Jika $t_{\text {hitung }}>t_{\text {tabel }}$, maka hipotesis diterima.

Jadi, karena dalam penelitian ini besarnya nilai $t_{\text {hitung }}$ lebih besar daripada $t_{\text {tabel }}$ maka disimpulkan bahwa hipotesis dalam penelitian ini diterima yaitu adanya pengaruh negatif signifikan biaya operasional terhadap laba usaha pada PT. Prima Transportasi.

\section{KESIMPULAN}

Berdasarkan hasil pengujian hipotesis, ditemukan $t_{\text {hitung }}$ lebih besar dari pada $t_{\text {tabel }}$, sehingga dapat disimpulkan bahwa biaya operasional berpengaruh negatif signifikan terhadap laba usaha pada PT. Prima Transportasi. Hasil uji regresi linear sederhana, menunjukkan persamaan regresi $\mathrm{Y}=383,670+0,134 \mathrm{X}$ dimana apabila dalam sebulan pada saat biaya operasional diketahui konstan $(X=0)$, maka diketahui laba usaha adalah sebesar Rp. 383,670. Jika dalam sebulan terjadi pengeluaran biaya operasional sebesar Rp. 1 maka diperkirakan hanya mampu menghasilkan perolehan laba usaha sebesar Rp. 0,134. Sementara ituhasil analisis koefisien korelasi yang dilakukan peneliti, ditemukan nilai korelasi bertanda positif yaitu sebesar 0,931 dimana berada di antara nilai pengaruh 0,901,00 yang menyatakan bahwa pengaruh korelasi antara biaya operasional terhadap laba usaha memiliki pengaruh yang sangat kuat, dan sesuai dengan hasil analisis koefisien 
determinasi ditemukan koefisien determinasi adalah sebesar 86,7\% yang berarti bahwa pengeluaran biaya operasional pada PT. Prima Transportasi memberikan pengaruh sebesar $86,3 \%$ terhadap perolehan laba usaha pada perusahaan tersebut, sedangkan 13,3\% lainnya dipengaruhi oleh faktor lain yang tidak diteliti dalam penelitian ini.

\section{SARAN}

Berdasarkan kesimpulan yang didapatkan, maka diharapkan PT. Prima Transportasi agar dapat menekan pengeluaran biaya operasional seefisien mungkin pada tiap bulannya, mengestimasi pengeluaran biaya tidak tetap dan meningkatkan volume pendapatan.

\section{DAFTAR PUSTAKA}

[1] Sawir, Agnes. 2003. Analisis Kinerja Keuangan dan Perencanaan Keuangan Perusahaan. Jakarta:Gramedia Pustaka Utama.

[2] Sutrisno. 2007. Manajemen Keuangan (Teori, konsep dan aplikasi). Yogyakarta:PT. Ekonisia.

[3] Syahrul. 2000. Kamus Akuntansi. Jakarta: Citra Harta Prima.

[4] Muljo, Hery Harjono. 2007. Akuntansi Keuangan Menengah. Yogyakarta: Graha Ilmu.

[5] Kuswadi. 2006. Analisis Keekonomian Proyek. Yogyakarta: Andi Offset.

[6] Syahrul dan Muhammad AfdiNizar. 2000. Pengaruh Biaya Operasional Terhadap Laba Komoditi Teh Kering pada PT perkebunan Nusantara VIII Jawa Barat. Bandung: Fakultas Ekonomi Universitas Komputer Indonesia.

[7] Nafarin, M. 2007. Penganggaran Perusahaan. Edisi ke 3. Jakarta: PT. Salemba Empat.

[8] Riyanto, Bambang. 2001. Dasar-Dasar Pembelanjaan Perusahaan. Edisi 4. Yogyakarta: BPFE.

[9] Juki, Umar. 2008. Pengaruh Biaya Operasional terhadap Profitabilitas pada PT. Kereta Api Indonesia (Persero). Skripsi Fakultas Ekonomi dan Bisnis Universitas Komputer Indonesia.

[10] Jusuf, Jopie. 2008. Analisis Kredit Untuk Account Officer. Cetakan ke 8. Jakarta: PT. Gramedia Pustaka Utama.

[11] Munawir. 2002. Analisis Laporan Keuangan. Yogyakarta:Liberty.

[12] Kuswadi. 2006. Analisis Keekonomian Proyek. Yogyakarta: Andi Offset. 